Penanggung Jawab

Ir. Kuswari, MP

Ketua Redaksi

Mulono Apriyanto, S.Tp, MP

\section{Dewan Redaksi}

Prof. Dr. Ir. Sudirman Yahya, M.Sc

Prof. Dr. Ir. Zairin

Prof. Dr.Ir. Umar Santoso

Prof. Dr. Ir. Sutarji, M.Apcc

Ir. AMD Junaidi A.N. M.Si

Nursida, SP. MP

Susi Salhan, SP MP

Kasmaruddin, S.Pi, M.Si

Dwi Sushanty, S.Pi, M.Si

Abdurrahman, S.Pi, M.Si

Andi Yusapri, S.Pi

Zinatal Hayati, SP

Elfi Yeni yusuf, SP

M. Dong, SP

Intan Sari, SP

Agus Nuroso, SP

\section{Produksi dan Lay-out}

Mulono Apriyanto, S.Tp, MP

Hasan Usman

Riki erviandi, SE

Said Fadli, SE

\section{Keuangan}

Marlina

Wirda Gustina, S.Pi

\section{Jurnal AGROBITEKPER}

Adalah jurnal ilmiah yang diterbitkan oleh fakultas Pertanian UNISI bekerjasama para ahli dibidang Agroteknologi, Agribisnis, Teknologi Pangan dan Budidaya Perairan. Korespondensi termasuk pengiriman artikel, promosi dan iklan dapat menghubungi alamat Fakutas Pertanian Kampus II UNISI Jl. Propinsi parit I pulau Palas Tembilahan Hulu.

\section{Jurnal AGROBITEKPER}

Terbit 2 kali setahun, mempublikasikan hasil-hasil penelitian dalam bidang pertanian, Agroteknologi, Agribisnis, Teknologi Pangan dan Budidaya Perairan serta bidang-bidang yang relevan dengan pertanian.

Menginformasikan berbagai paket industry, ulasan ilmiah, komunikasi singkat dan informasi lain mngenai perkembangan teknologi dan industri pertanian.

\section{Jurnal AGROBITEKPER}

Menerima tulisan, artikel dan ulasan ilmiah dari civitas akademika maupun pihak luar Fakultas Pertanian, Promosi dan iklan. Iklan dapat berupa produk baru, rancangan proses dan peralatan serta pelayanan dan jasa yang akan menarik minat peneliti di Lembaga-lembaga pemerintah maupun para pakar ahli dibidang pertanian dan yang relevan. Informasi mengenai biaya dan pemasangan iklan dapat diperoleh langsung di sekretariat jurnal AGROBITEKPER Fakultas Pertanian UNISI telp. 07687000125.

\section{Jurnal AGROBITEKPER}

Mengucapkan terima kasih atas banyaknya partisipassi naskah dari para penulis. Sehubungan dengan keterbatasan mitra bestari dan jumlah halaman jurnal, kami mohon kesabaran para penulis dalam menunggu giliran publikasi, serta dapat mentaati tenggat waktu pengembalian naskah hasil perbaikan. 


\title{
UJI KONSENTRASI PUPUK GANDASIL D DAN GA (Gibberillic Acid) TERHADAP PERTUMBUHAN BIBIT BERANGAN (Castaneae)
}

\author{
Oleh \\ Fathurrahman, Ernita, M. Aslam, Gunawan, S \\ Laboratorium Bioteknologi Fakultas Pertanian Universitas Islam Riau, \\ Jl. Kaharuddin Nasution Km. 11 Perhentian Marpoyan Pekanbaru 28284 Riau. \\ Telp: 0761-72126 ext 123, Fax : 0761-674834
}

\begin{abstract}
ABSTRAK
Penelitian dengan judul "Uji Konsentrasi Pupuk Gandasil D dan GA (Gibberillic Acid) Terhadap Pertumbuhan Bibit Berangan (Castaneae)", telah dilaksanakan di Rumah Setengah Bayang Universitas Islam Riau Pekanbaru. Tujuan penelitian ini adalah untuk mendapatkan kombinasi konsentrasi Gandasil D dan GA yang memberikan pengaruh terbaik terhadap pertumbuhan bibit berangan didalam polybag.

Rancangan yang digunakan dalam penelitian ini adalah Rancangan Acak Lengkap (RAL) secara faktorial yang terdiri dari dua faktor dan tiga ulangan. Faktor pertama adalah pemberian Gandasil $\mathrm{D}$, terdiri dari 4 taraf yaitu : $\mathrm{D}_{0}$ (tanpa pemberian Gandasil $\mathrm{D}$ ), $\mathrm{D}_{1}$ (pemberian Gandasil D $1 \mathrm{~g} / \mathrm{l}$ air), $\mathrm{D}_{2}$ (pemberian Gandasil D $2 \mathrm{~g} / \mathrm{l}$ air), $\mathrm{D}_{3}$ (pemberian Gandasil D $3 \mathrm{~g} / \mathrm{l}$ air). Sedangkan faktor kedua adalah pemberian GA, terdiri dari empat taraf yaitu : $\mathrm{G}_{0}$ (tanpa pemberian GA), $\mathrm{G}_{1}$ (pemberian GA $10 \mathrm{mg} / \mathrm{l}$ air), $\mathrm{G}_{2}$ (pemberian GA $20 \mathrm{mg} / \mathrm{l}$ air), $\mathrm{G}_{3}$ (pemberian GA $30 \mathrm{mg} / \mathrm{l}$ air). Parameter yang diamati adalah tinggi tanaman $(\mathrm{cm})$, jumlah daun (helai), panjang akar $(\mathrm{cm})$, volume akar $\left(\mathrm{cm}^{3}\right)$, berat kering tanaman (gram).

Data pengamatan dianalisis secara statistik dan uji lanjut mengunakan BNJ pada taraf 5\%. Secara tunggal pemberian Gandasil $\mathrm{D}$ berpengaruh nyata terhadap tinggi tanaman, volume akar, dan berat kering tanaman dengan perlakuan terbaik adalah perlakuan $\mathrm{D}_{3}(3 \mathrm{~g} / \mathrm{l})$. Secara tunggal pemberian GA berpengaruh nyata terhadap tinggi tanaman, panjang akar, volume akar, dan berat kering tanaman dengan perlakuan terbaik adalah perlakuan $\mathrm{G}_{3}(30$ $\mathrm{mg} / \mathrm{l})$. Hasil penelitian secara interaksi pemberian Gandasil D dan GA berpengaruh nyata terhadap volume akar dengan perlakuan terbaik $\mathrm{D}_{3} \mathrm{G}_{3}$.
\end{abstract}

Kata Kunci : Berangan (Castaneae), Gibberillic Acid(GA), Gandasil D, Pertumbuhan

\section{CONCENTRATION TEST OF FERTILIZER Gandasil D and GA (Gibberillic Acid) TO GROWTH OF CHESTNUT SEEDS (Castaneae)}

\begin{abstract}
Study on Fertilizer Concentration Test of Gandasil D and GA (Gibberillic Acid) to the Growth of Seedling Berangan (Castaneae)", was carried out at the shading net of Islamic University of Riau. The aim of this study was to obtain a combination of Gandasil D and GA concentration that gives the best effect on the growth of chestnut seeds in polybags. The Completely Randomize Design was used in this study with factorial which consisted of two factors and three replications. The first factor is the provision Gandasil D, consists of four standards, namely: $\mathrm{D}_{0}$ (without Gandasil D), $\mathrm{D}_{1}$ (Gandasil D $1 \mathrm{~g} / 1$ water), $\mathrm{D}_{2}$ (Gandasil D $2 \mathrm{~g}$ / 1 water), and $\mathrm{D}_{3}$ (Gandasil D $3 \mathrm{~g} / \mathrm{l}$ water). The second factor is the application of GA,
\end{abstract}


consisting of four standard, namely: $\mathrm{G}_{0}$ (without GA), $\mathrm{G}_{1}$ (GA $10 \mathrm{mg} / \mathrm{l}$ water), $\mathrm{G}_{2}$ (GA 20 $\mathrm{mg} / \mathrm{l}$ water), $\mathrm{G}_{3}$ (GA $30 \mathrm{mg} / \mathrm{l}$ water). The parameters measured were plant height $(\mathrm{cm})$, number of leaves (blade), root length $(\mathrm{cm})$, root volume $(\mathrm{cm} 3)$, plant dry weight (grams).

Data were statistically analyzed using BNJ-up and test at the level of $5 \%$. The results in the interaction of Gandasil D and GA significantly affected the volume of roots with the best treatment of $\mathrm{D}_{3} \mathrm{G}_{3}$. In the single application, Gandasil $\mathrm{D}$ significantly affected plant height, root volume, and dry weight of plants with the best treatment was the treatment of $D_{3}(3 \mathrm{~g} / \mathrm{l})$. In a single application, GA significantly affected plant height, root length, root volume and dry weight of plants with the best treatment is the treatment of $\mathrm{G}_{3}(30 \mathrm{mg} / \mathrm{l})$.

\section{Keyword : Chestnut (Castaneae), Gibberillic Acid(GA), Gandasil D, Growth}

\section{PENDAHULUAN}

Tanaman berangan merupakan tanaman hutan dan di sebagian wilayah Indonesia tumbuh dan berkembang di hutan primer, hutan skunder, dan disemak belukar. Bagian tanaman ini semua mempunyai manfaat dan khasiat. Pemanfaatan tanaman berangan dimulai dari buah yang dapat langsung dikonsumsi dalam bentuk segar maupun setelah diolah seperti digongseng ataupun dijadikan tepung. Buah berangan banyak mengandung kalori, unsur-unsur mineral, berkhasiat untuk memperkuat jariangan otot, anti anemia, mengobati asam lambung, pencegah terjadinya infeksi. Daun dari tanaman ini juga dapat dimanfaatkan untuk makanan ternak sedangkan kayunya sangat kuat sehingga dapat dijadikan bahan bangunan serta untuk ukiran karena tahan dari pengaruh iklim dan cuaca.

Selain banyak manfaat berangan juga memiliki kandungan gizi yang sangat tinggi, dimana dalam 100 gram mengandung 180-200 mg kalori, 3-4 gram protein, 2 gram lipid, 28 gram pati, 3-8 gula terlarut, 32 gram karbohidrat, 14 gram serat, 0,1 gram besi, 0,8 gram fosfor, 0,1 gram sodium, 4 gram kalsium, 0,02 gram vitamin B1, 0,03 gram vitamin B2, 0,14 gram vitamin $\mathrm{B} 3$, dan 5 gram vitamin $\mathrm{C}$ (Fathurrahman dan Rosyadi, 2009).

Dalam usaha perluasan areal pertanaman berangan di daerah baru, terutama dalam skala besar memerlukan ketersediaan bibit yang memiliki kualitas baik dan dalam jumlah yang banyak, maka untuk mengatasinya dapat dilakukan dengan perbanyakan secara kultur jaringan dan perbanyakan konvensional. Untuk mempercepat pertumbuhan bibit berangan dapat dilakukan beberapa cara, antara lain dengan panambahan pupuk dan menggunakan zat pengatur tumbuh. Dengan dilakukannya pemupukan dan penambahan zat pengatur tumbuh bibit berangan dapat lebih cepat dipindahkan kelapangan.

Pemupukan merupakan hal yang mutlak dilakukan guna mempercepat pertumbuhan tanaman. Pemupukan dapat dilakukan melalui akar (Root application) maupun melalui daun (Foliar application). Pemberian pupuk melalui daun mempunyai keuntungan yaitu memberikan pengaruh yang lebih cepat terlihat karena penyerapan unsur hara terjadi langsung stomata dan lapisan epidermis daun.

Lingga (2001), mengemukakan bahwa Gandasil D merupakan pupuk anorganik yang mengandung unsur hara makro dan unsur hara mikro yang dapat digunakan pada masa pertumbuhan vegetatif serta dapat memperkuat sistem perakaran tanaman. Giberellin merupakan hormon yang dihasilkan oleh tanaman yang biasanya bergerak dari bagian tanaman yang menghasilkan hormon giberellin menuju kebagian tanaman yang lainnya. Senyawa giberellin bagi tanaman berfungsi dalam menstimulasi pembelahan sel, perpanjangan sel ataupun keduanya (Dwidjoseputro, 1983). 
Dengan menggunakan zat pengatur tumbuh terdapat beberapa keuntungan diantaranya : mempercepat pertumbuhan tunas dan daun, merangsang pertumbuhan akar, mempercepat keluarnya akar bagi tanaman muda (bibit), membantu dalam menyerap unsur hara, mencegah gugur daun, memperkaya pertumbuhan vegetatif dan meningkatkan proses fotosintesis dan lain-lain. Proses masuknya zat dalam daun terjadinya difusi dan osmosis melalui stomata. Membukanya stomata merupakan proses mekanis yang diatur oleh tekanan turgor dari sel penutup. Meningkatnya tekanan turgor akan merangsang membukanya stomata dan pada saat itu unsur hara akan terdifusi kedalam stomata bersama-sama dengan masuknya air ( Setyamidjaya, 1986). Jika penggunaan pupuk dan ZPT maksimal dan memberikan respon yang baik bagi pertumbuhan dan perkembangan bibit berangan, maka perbanyakan massal terhadap tanaman ini diharapkan menjadi sumber bibit untuk reboisasi hutan kritis dan penghijauan di perkotaan.

Tujuan Penelitian Untuk mengetahui Konsentrasi Gandasil D dan GA (Gibberillic Acid) yang terbaik terhadap pertumbuhan bibit berangan (Castaneae).

\section{BAHAN DAN METODE}

Penelitian telah dilaksanakan di
rumah setengah bayang Faperta Universitas Islam Riau, Pekanbaru. Penelitian ini telah dilaksanakan selama tiga bulan, yang telah dilaksanakan pada bulan April sampai bulan Juni 2010. Bahan yang digunakan dalam penelitian ini adalah bibit berangan yang berumur tiga bulan, Gandasil D, Giberrellin, Dithane M45, Furadan, polybag, kertas label, tanah hitam, pupuk kompos, paku.
Sedangkan alat-alat yang digunakan adalah gelas ukur, pisau, gunting, meteran besi, pena, handsprayer, cangkul, martil, termometer, timer, bak plastik, oven, kamera.

\section{METODE PENELITIAN}

Penelitian ini menggunakan Rancangan Acak Lengkap (RAL) yang terdiri dari dua faktor. Faktor pertama adalah konsentrasi Gandasil D (D) yang terdiri dari empat taraf dan faktor kedua adalah konsentrasi GA (G) yang juga terdiri dari empat taraf sehingga didapat 16 kombinasi perlakuan dengan tiga kali ulangan. Setiap perlakuan terdiri dari empat bibit dan tiga bibit dijadikan sampel. Jumlah keseluruhan bibit adalah 192 batang. Faktor D adalah konsentrasi Gandasil $\mathrm{D}$ terdiri dari $\mathrm{D}_{0}=$ tanpa pemberian Gandasil $\mathrm{D}, \mathrm{D}_{1}=$ pemberian Gandasil $\mathrm{D} 1 \mathrm{~g} / \mathrm{l}$ air, $\mathrm{D}_{2}=$ pemberian Gandasil D $2 \mathrm{~g} / \mathrm{l}$ air dan $\mathrm{D}_{3}=$ pemberian Gandasil D $3 \mathrm{~g} / \mathrm{l}$ air. Untuk GA faktornya terdiri dari $\mathrm{G}_{0}=$ tanpa pemberian $\mathrm{GA}, \mathrm{G}_{1}=$ pemberian GA $10 \mathrm{mg} / \mathrm{l}$ air, $\mathrm{G}_{2}=$ pemberian GA $20 \mathrm{mg} / \mathrm{l}$ air dan $\mathrm{G}_{3}=$ pemberian GA $30 \mathrm{mg} / \mathrm{l}$ air. Uji statistik lanjut yang dilakukan adalah uji lanjut Beda Nyata Jujur (BNJ) pada taraf 5\%.

\section{HASIL DAN PEMBAHASAN \\ Tinggi Tanaman (cm)}

Hasil pengamatan terhadap tinggi tanaman setelah dianalisis sidik ragam menujukan bahwa interaksi antara Gandasil D dan GA tidak berpengaruh nyata terhadap tinggi tanaman, akan tetapi pemberiannya secara tunggal berpengaruh nyata terhadap tinggi tanaman. Rerata tinggi tanaman berangan menurut Uji Lanjut BNJ pada taraf $5 \%$ dapat dilihat pada Tabel 1. 
Tabel 1. Rerata tinggi tanaman berangan dengan perlakuan Gandasil D dan perlakuan GA (cm)

\begin{tabular}{|c|c|c|c|c|c|}
\hline \multirow[t]{2}{*}{ Konsentrasi D } & \multicolumn{4}{|c|}{ Konsentrasi GA } & \multirow[t]{2}{*}{ Rerata } \\
\hline & $\mathrm{G}_{0}(0 \mathrm{mg} / \mathrm{l})$ & $\mathrm{G}_{1}(10 \mathrm{mg} / \mathrm{l})$ & $\mathrm{G}_{2}(20 \mathrm{mg} / \mathrm{l})$ & $\mathrm{G}_{3}(30 \mathrm{mg} / \mathrm{l})$ & \\
\hline $\mathrm{D}_{0}(0 \mathrm{~g} / \mathrm{l})$ & 8,84 & 9,09 & 10,06 & 10,60 & $9,65(\mathrm{c})$ \\
\hline $\mathrm{D}_{1}(1 \mathrm{~g} / \mathrm{l})$ & 9,43 & 9,45 & 10,17 & 10,63 & $9,92(b c)$ \\
\hline $\mathrm{D}_{2}(2 \mathrm{~g} / \mathrm{l})$ & 10,17 & 10,31 & 10,35 & 10,75 & 10,39 (b) \\
\hline $\mathrm{D}_{3}(3 \mathrm{~g} / \mathrm{l})$ & 10,43 & 11,23 & 11,46 & 11,95 & 11,27 (a) \\
\hline Rerata & $9,72(\mathrm{c})$ & $10,02(b)$ & $10,51(a b)$ & 10,98 (a) & \\
\hline
\end{tabular}

KK : $6,13 \% \quad$ BNJ D/G : 0,69

Angka-angka pada baris dan kolom yang diikuti huruf kecil yang sama menunjukan tidak berbeda nyata menurut Uji Lanjut BNJ taraf $5 \%$.

Berdasarkan Tabel 1 perlakuan terbaik pada pemberian Gandasil D adalah pada perlakuan D3 (3 g/l) dengan rata-rata tinggi tanaman $11,27 \mathrm{~cm}$, hal ini disebabkan pada konsentrasi tersebut memenuhi kebutuhan bibit berangan. Sedangkan pada perlakuan $\mathrm{D}_{0}$ menunjukan pertumbuhan tinggi tanaman lambat, disebabkan tanpa diberikan perlakuan dan unsur hara dalam media belum mencukupi dalam pertumbuhan dan pembentukan sel.

Hidayat (2002) mengemukakan, pemberian Gandasil D berpengaruh nyata terhadap tinggi tanaman Kailan (Brassica oleraceae Var. Acephala DC) dengan perlakuan terbaik $\quad 1 \mathrm{gr} / \mathrm{l}$ air dengan tinggi tanaman $19,19 \mathrm{~cm}$, dibandingkan tanpa pemberian Gandasil D tingginya hanya $15,15 \mathrm{~cm}$. Setyamidjaya (1986) mengemukakan, bahwa konsensentrasi hara yang tinggi dapat menyebabkan kerusakan pada daun. Perlakuan terbaik pemberian $\mathrm{GA}$ adalah pada perlakuan $\mathrm{G}_{3}$ (30 $\mathrm{mg} / \mathrm{l})$ dengan rata-rata tinggi tanaman $10,98 \mathrm{~cm}$.

Pemberian GA diperoleh tinggi tanaman tomat mencapai $85,45 \mathrm{~cm}$ pada konsentrasi $20 \mathrm{mg} / \mathrm{l}$ air dibandingkan tanpa GA tingginya 73,21 cm. (Ernita, 2004). Nurbaya dkk (2001), mengemukakan pemberian Giberellin berpengaruh terhadap tinggi tanaman mentimun 3,02 m dengan konsentrasi $5 \mathrm{mg} / \mathrm{l}$ air, dibandingkan kontrol hanya 1,57 $\mathrm{m}$. Lakitan (1996), mengemukakan bahwa salah satu peranan Gibberellin adalah dapat memacu pembesaran dan perpanjangan sel yang mengarah pada perpanjangan batang, sehingga tinggi tanaman dapat terdorong. Jika konsentrasi hormon dalam tanaman terbatas dan menghambat perpanjangan batang, maka penambahan hormon dari luar akan memberikan pengaruh yang memuaskan (Trimulat, 2003).

\section{Jumlah Daun (helai)}

Hasil pengamatan terhadap jumlah daun setelah dianalisis sidik ragam menujukan bahwa secara interaksi dan secara tunggal pemberian Gandasil D dan GA tidak berpengaruh nyata terhadap jumlah daun. Rerata jumlah daun dapat dilihat pada Tabel 2. 
Tabel 2. Rerata jumlah daun tanaman berangan dengan perlakuan Gandasil D dan perlakuan GA (helai).

\begin{tabular}{|c|c|c|c|c|c|}
\hline \multirow[t]{2}{*}{ Konsentrasi D } & \multicolumn{4}{|c|}{ Konsentrasi GA } & \multirow{2}{*}{$\begin{array}{c}\text { Konsentrasi } \\
\text { GA }\end{array}$} \\
\hline & $\mathrm{G}_{0}(0 \mathrm{mg} / \mathrm{l})$ & $\mathrm{G}_{1}(10 \mathrm{mg} / \mathrm{l})$ & $\mathrm{G}_{2}(20 \mathrm{mg} / \mathrm{l})$ & $\mathrm{G}_{3}(30 \mathrm{mg} / \mathrm{l})$ & \\
\hline $\mathrm{D}_{0}(0 \mathrm{~g} / \mathrm{l})$ & 8,77 & 9,44 & 9,88 & 9,44 & 9,38 \\
\hline $\mathrm{D}_{1}(1 \mathrm{~g} / \mathrm{l})$ & 9,55 & 9,77 & 9,55 & 9,55 & 9,61 \\
\hline $\mathrm{D}_{2}(2 \mathrm{~g} / \mathrm{l})$ & 9,44 & 9,66 & 9,66 & 9,66 & 9,60 \\
\hline$D_{3}(3 \mathrm{~g} / 1)$ & 9,44 & 9,44 & 9,66 & 9,88 & 9,60 \\
\hline Rerata & 9,30 & 9,58 & 9,69 & 9,63 & \\
\hline
\end{tabular}

Angka-angka pada baris dan kolom yang sama tidak berbeda nyata menurut Uji F.

Pada Tabel 2 menunjukan pemberian Gandasil D dan GA tidak berbeda nyata terhadap jumlah daun. Hal ini disebabkan Gandasil D dan giberellin yang diberikan hanya mengakibatkan pertambahan lebar daun bukan pertambahan jumlah daun. Anonim (1991), mengemukakan keunggulan Gandasil D adalah sebagai penunjang pertumbuhan vegetatif tanaman dan mengatasi kekurangan unsur hara mikro dan hal yang sama juga dikemukakan Nurbaya dkk. (2001). Salysbury dan Ross (1985), mengemukakan daun muda menjadi tempat umum sintesis giberellin.

Dwijosaputro

mengemukakan daun berasal dari titik tumbuh batang. Primordia daun merupakan tonjolan yang pertama yang membalut pada sisi titik tumbuh. Hakim (1986), mengemukakan kandungan zat hijau daun (klorofil) sangat menentukan jalannya proses fotosintesis.

\section{Panjang Akar (cm)}

Hasil pengamatan terhadap panjang akar setelah dianalisis sidik ragam menujukan bahwa interaksi antara Gandasil D dan GA serta pemberian Gandasil D secara tunggal tidak berpengaruh nyata terhadap panjang akar, akan tetapi pemberian GA secara tunggal berpengaruh nyata terhadap panjang akar. Rerata panjang akar tanaman berangan menurut Uji Lanjut BNJ pada taraf $5 \%$ dapat dilihat pada Tabel 3. 
Tabel 3. Rerata panjang akar tanaman berangan dengan perlakuan Gandasil D dan perlakuan GA (cm).

\begin{tabular}{cccccc}
\hline $\begin{array}{c}\text { Konsentrasi } \mathrm{D} \\
(\mathrm{g} / \mathrm{l})\end{array}$ & $\mathrm{G}_{0}(0 \mathrm{mg} / \mathrm{l})$ & $\mathrm{G}_{1}(10 \mathrm{mg} / \mathrm{l})$ & $\mathrm{G}_{2}(20 \mathrm{mg} / \mathrm{l})$ & $\mathrm{G}_{3}(30 \mathrm{mg} / \mathrm{l})$ & Konsentrasi \\
\hline $\mathrm{D}_{0}(0 \mathrm{~g} / \mathrm{l})$ & 9,13 & 9,53 & 10,07 & 11,13 & 9,97 \\
$\mathrm{D}_{1}(1 \mathrm{~g} / \mathrm{l})$ & 9,27 & 10,07 & 10,27 & 11,17 & 10,19 \\
$\mathrm{D}_{2}(2 \mathrm{~g} / \mathrm{l})$ & 10,27 & 10,43 & 10,60 & 11,17 & 10,61 \\
$\mathrm{D}_{3}(3 \mathrm{~g} / \mathrm{l})$ & 10,40 & 10,50 & 10,60 & 11,23 & 10,68 \\
Rerata & $9,77(\mathrm{~b})$ & $10,13(\mathrm{~b})$ & $10,38(\mathrm{ab})$ & $11,17(\mathrm{a})$ & \\
\hline
\end{tabular}

KK $: 8,13 \% \quad$ BNJ G : 0,93

Angka-angka pada baris dan kolom yang diikuti oleh huruf kecil yang sama tidak berbeda nyata menurut Uji Lanjut BNJ pada taraf $5 \%$.

Dari Tabel 3 dapat dilihat bahwa hanya pada perlakuan tunggal pada konsentrasi GA yang berbeda nyata dimana perlakuan $\mathrm{G}_{3}$ merupakan terbaik diperoleh panjang akar $\quad 11,17 \mathrm{~cm}$. Hal ini diduga konsentrasi $30 \mathrm{mg} / \mathrm{l}$ air dianggap telah memenuhi konsentrasi yang tepat dalam merangsang pembelahan sel dan perbesaran sel akar.

Giberellin dalam jumlah sedikit dapat meningkatkan atau memacu pertumbuhan vegetatif dan generatif terutama dalam pembelahan dan pembesaran sel yang terdapat pada jaringan tanaman. Hal tersebut didukung oleh Wattimena (1987), menyatakan untuk merangsang dan mempercepat pertumbuhan akar, diantaranya adalah menggunakan zat pengatur tumbuh. Untuk tumbuhnya suatu tanaman, akar mempunyai peranan yang sangat penting disamping untuk menyerap air dan mineral akar juga berfungsi sebagai alat bernafas.

\section{Volume Akar $\left(\mathrm{cm}^{3}\right)$}

Hasil pengamatan terhadap volume akar setelah dianalisis sidik ragam menujukan bahwa secara interaksi dan secara tunggal pemberian Gandasil D dan GA berpengaruh nyata terhadap volume akar seperti terlihat pada Tabel 4.

Tabel 4. Rerata volume akar tanaman berangan dengan perlakuan Gandasil D dan perlakuan $\mathrm{GA}\left(\mathrm{cm}^{3}\right)$.

\begin{tabular}{|c|c|c|c|c|c|}
\hline \multirow[t]{2}{*}{ Konsentrasi D } & \multicolumn{4}{|c|}{ Konsentrasi GA } & \multirow{2}{*}{$\begin{array}{c}\text { Konsentras } \\
\text { GA }\end{array}$} \\
\hline & $\mathrm{G}_{0}(0 \mathrm{mg} / \mathrm{l})$ & $\mathrm{G}_{0}(10 \mathrm{mg} / \mathrm{l})$ & $\mathrm{G}_{0}(20 \mathrm{mg} / \mathrm{l})$ & $\mathrm{G}_{0}(30 \mathrm{mg} / \mathrm{l})$ & \\
\hline $\mathrm{D}_{0}(0 \mathrm{~g} / \mathrm{l})$ & $2,30(\mathrm{~d})$ & $2,67(\mathrm{~cd})$ & $3,00(\mathrm{c})$ & $3,33(b c)$ & $2,82(\mathrm{c})$ \\
\hline $\mathrm{D}_{1}(1 \mathrm{~g} / \mathrm{l})$ & $2,67(\mathrm{~cd})$ & $3,00(\mathrm{c})$ & $3,33(b c)$ & $3,67(a b)$ & $3,17(\mathrm{bc})$ \\
\hline $\mathrm{D}_{2}(2 \mathrm{~g} / \mathrm{l})$ & $3,00(\mathrm{c})$ & $3,00(\mathrm{c})$ & $3,67(b c)$ & $4,00(a b)$ & $3,42(b)$ \\
\hline $\mathrm{D}_{3}(3 \mathrm{~g} / \mathrm{l})$ & $3,33(b c)$ & $4,00(a b)$ & 4,33 (ab) & 4,67 (a) & 4,08 (a) \\
\hline Rerata & $2,82(\mathrm{c})$ & $3,17(b c)$ & $3,58(a b)$ & 3,92 (a) & \\
\hline KK : $12,58 \%$ & DIV & $G: 0,47$ & BNJ DC & & \\
\hline
\end{tabular}


Angka-angka pada baris dan kolom yang diikuti oleh huruf kecil yang sama tidak berbeda nyata menurut Uji Lanjut BNJ pada taraf $5 \%$.

Perlakuan terbaik secara interaksi adalah pada perlakuan $\mathrm{D}_{3} \mathrm{G}_{3}$ dimana volume akar yang dihasilkan adalah 4,67 $\mathrm{cm}^{3}$ dan perlakuan terendah adalah pada perlakuan $\mathrm{D}_{0} \mathrm{G}_{0}$ yang menghasilkan volume akar $2,30 \mathrm{~cm}^{3}$. Pada perlakuan $\mathrm{D}_{3} \mathrm{G}_{3}$ diduga interaksi perlakuan zat pengatur tumbuh telah memenuhi pertumbuhan akar.

Zat pengatur tumbuh juga mempengaruhi pertambahan volume akar karena dengan meningkatnya pertumbuhan akar maka volume akar juga akan meningkat. Kalathan (1985), menyatakan penggunaan GA yang tepat dapat memberikan rangsangan terhadap bagianbagian tanaman antara lain merangsang pertumbuhan tunas dan juga pembesaran organ. Abidin (1985), mengemukakan bahwa zat perangsang tumbuh yang ada pada tanaman terdiri dari lima kelompok yaitu Auksin, Gibberellin, Sitokinin, Etilen dan Inhibitor yang mempunyai fungsi dalam merangsang metabolisme tanaman serta meningkatkan pembelahan sel. ZPT dapat mempercepat pertumbuhan akar, aktif dalam jumlah kecil $\left(10^{-6}\right.$ sampai $10^{-5}$ uM). Selanjutnya Gultom (2006), mengemukakan pemberian $\mathrm{GA}_{3}$ berpengaruh terhadap berat kering akar tanaman padi.

\section{Berat Kering Tanaman (gram)}

Hasil pengamatan terhadap berat kering tanaman setelah dianalisis sidik ragam menujukan bahwa hanya perlakuan Gandasil D dan GA secara tunggal memberikan pengaruh yang nyata terhadap berat kering tanaman seperti terlihat pada Tabel 5.

Tabel 5. Rerata berat kering tanaman berangan dengan perlakuan Gandasil D dan perlakuan GA (gram).

\begin{tabular}{cccccc}
\hline Konsentrasi D & \multicolumn{5}{c}{ Konsentrasi GA } \\
& $\mathrm{G}_{0}(0 \mathrm{mg} / \mathrm{l})$ & $\mathrm{G}_{1}(10 \mathrm{mg} / \mathrm{l})$ & $\mathrm{G}_{2}(20 \mathrm{mg} / \mathrm{l})$ & $\mathrm{G}_{3}(30 \mathrm{mg} / \mathrm{l})$ & Rerata \\
\hline $\mathrm{D}_{0}(0 \mathrm{~g} / \mathrm{l})$ & 2,13 & 2,73 & 3,70 & 4,60 & $3,29(\mathrm{~b})$ \\
$\mathrm{D}_{1}(1 \mathrm{~g} / \mathrm{l})$ & 2,67 & 3,20 & 4,17 & 5,03 & $3,77(\mathrm{~b})$ \\
$\mathrm{D}_{2}(2 \mathrm{~g} / \mathrm{l})$ & 3,37 & 4,17 & 5,13 & 6,27 & $4,73(\mathrm{a})$ \\
$\mathrm{D}_{3}(3 \mathrm{~g} / \mathrm{l})$ & 3,87 & 3,93 & 5,43 & 6,80 & $5,00(\mathrm{a})$ \\
Rerata & $3,01(\mathrm{c})$ & $3,50(\mathrm{c})$ & $4,60(\mathrm{~b})$ & $5,67(\mathrm{a})$ & \\
\hline
\end{tabular}

KK $: 11,41 \% \quad$ BNJ D/G : 0,53

Angka-angka pada baris dan kolom yang diikuti oleh huruf kecil yang sama tidak berbeda nyata menurut Uji Lanjut BNJ pada taraf $5 \%$.

Pada Tabel 5 menunjukan bahwa pada perlakuan tunggal memberi pengaruh nyata terhadap berat kering. Pada perlakuan $\mathrm{D}_{3}(3 \mathrm{~g} / \mathrm{l})$ diperoleh berat kering tanaman berangan adalah 5,00 gram, dibandingkan $\mathrm{D}_{0}(0 \mathrm{~g} / \mathrm{l})$ hanya 3,29 gram.
Diduga pada perlakuan $\mathrm{D}_{3}$ peningkatan berat kering sudah maksimal. Peningkatan berat kering tanaman merupakan proses diferensiasi yang mempunyai tiga syarat : 1) Hasil amilasi tersedia didalam keaadan berlebihan untuk dapat dimanfaatkan 
dalam kegiatan metabolik, 2) Temperatur yang menguntungkan, 3) Terdapat sistem enzim yang tepat sebagai perantara proses penebalan dinding sel, deposit dari sebagian sel yang berakibat peningkatan bobot suatu tanaman.

Heriyanto (2005) mengemukakan, pemberian Gandasil D memberikan pengaruh nyata terhadap berat kering tanaman mimba denga perlakuan terbaik 3 gr/l air, menghasilkan $15 \mathrm{~g}$ dibandingkan kontrol menghasilkan $6 \mathrm{~g}$. Hasil penelitian Hidayat (2002), konsentrasi 1 gram menghasilkan berat kering tanaman 4,18 gram dibandingkan kontrol hanya menghasilkan berat 3,8 gram pada tanaman kailan. Harjadi (1982), menyatakan peningkatan berat kering tanaman terjadi jika proses fotosintesis lebih besar dari proses respirasi.

Secara tunggal perlakuan $\mathrm{G}_{3}$ diperoleh berat kering tertinggi yaitu 5,67 gram, dibandingkan Kontrol hanya 3,01 gram. Diduga pada perlakuan $\mathrm{G}_{3}$ telah meningkatkan pembelahan dan perbesaran sel secara maksimal, sehingga berat kering tanaman juga akan meningkat. Perlakuan gibberellin juga memberikan pengaruh yang nyata pada tanaman kailan, dimana perlakuan $10 \mathrm{mg} / \mathrm{l}$ air merupakan perlakuan yang terbaik dengan berat 4,32 gram dibandingkan perlakuan terendah 0,1 $\mathrm{mg} / \mathrm{l}$ air dengan berat kering tanaman 3,56 gram (Hidayat, 2002).

\section{KESIMPULAN}

Dari hasil penelitian yang telah dilakukan disimpulkan bahwa pemberian Gandasil D berpengaruh nyata terhadap tinggi tanaman, volume akar, dan berat kering tanaman dengan perlakuan terbaik adalah perlakuan. pemberian GA berpengaruh nyata terhadap tinggi tanaman, panjang akar, volume akar, dan berat kering tanaman. Secara interaksi pemberian Gandasil D dan GA berpengaruh nyata terhadap volume akar dengan perlakuan terbaik $\quad \mathrm{D}_{3} \mathrm{G}_{3}(3 \mathrm{~g} / \mathrm{l}$ Gandasil D dan $30 \mathrm{ml} / \mathrm{l} \mathrm{GA}$ ).

\section{DAFTAR PUSTAKA}

Abidin, Z. 1985. Dasar-Dasar Tentang Zat Pengatur Tumbuh. Angkasa Bandung. Bandung.

Anonim. 1991. Prospek Penggunaan Pupuk Daun. Trubus. Jakarta.

Dwidjoseputro. 1983. Dasar-Dasar Fisiologi Tumbuhan. PT. Gramedia Jakarta.

Ernita. 2004. Penggunaan Plant Catalyst dan Giberellin (GA3) pada Tanaman Tomat (Lycopersicum esculentum L). Dinamika Pertanian Volume XIX(168-178). Fakultas Pertanian. Universitas Islam Riau.

Fathurrahman dan Rosyadi. 2009. Tanaman Berangan (Castaneae) Mengenal Lebih Dekat dan Mempercepat Perbanyakannya. Penerbit UIR Press. Pekanbaru.

Gultom, H. 2006. Pengaruh Fotopriode dan Penggunaan GA3 Terhadap Pertumbuhan dan Produksi Tanaman Padi. Dinamika Pertanian Volume XXI (32-39). Fakultas Pertanian. Universitas Islam Riau.

Hakim, N. Nyakpa, M. Lubis, A. Nugroho, S. G. Diha, Hong Goban dan Bacley, H. 1986. Dasar-Dasar Ilmu Tanah. Universitas Lampung.

Harjadi. 1982. Pengantar Agronomi. PT. Gramedia. Jakarta.

Heriyanto. 2005. Pengaruh Pupuk Kandang dan Gandasil D Terhadap Pertumbuhan Bibit Tanaman Mimba (Azadirachta indica A juss). Skripsi Fakultas Pertanian. Universitas Islam Riau. Pekanbaru. 
Hidayat, S. 2002. Pengaruh Penggunaan Gandasil D dan Gibberellin (GA) Terhadap Pertumbuhan dan Hasil Kailan (Brassila oraceae Var. Acephala DC). Fakultas Pertanian. Universitas Islam Riau. Pekanbaru.

Kalathan, C. 1985. Zat Pengatur Tumbuh Tanaman. Melipat Gandakan Produksi dan Sarana Pendapatan. Dekamon. Jakarta.

Lingga, P. 1996. Petunjuk Penggunaan Pupuk. Penebar Swadaya. Jakarta.

Lakitan. 1996. Fisiologi Pertumbuhan dan Perkembangan Tanaman. PT. Raja Grafindo Persada. Jakarta.

Nurbaya, Jumin dan Maizar. 2001. Pemberian GA3 Terhadap Pertumbuhan Mentimun (Cucumis sativus L) Secara Hidroponik.
Dinamika Pertanian Volume XVI (45-52). Fakultas Pertanian. Universitas Islam Riau.

Salysburi dan Ross. 1985. Fisiologi Tumbuhan ITB. Bandung. 343 hal.

Setyamidjaya, D. 1986. Pupuk dan Pemupukan. CV. Simplex. Jakarta.

Trimulat. 2003. Membuat dan Memanfaatkan Pupuk Kascing Pupuk Organik Berkualitas. PT AgroMedia Pustaka. Jakarta.

Wattimena, G. A. 1987. Zat Pengarur Tumbuh Tanaman. Lab. Kultur Jaringan Tanaman PAU Bioteknologi Institut Pertanian Bogor. 